\title{
Course and Student Management System Based on ABET Computing Criteria
}

\author{
Sahar A. El_Rahman ${ }^{1,2}$ \\ ${ }^{1}$ Electronics, Computers Systems and Communication- Electrical Department, Faculty of Engineering-Shoubra, Benha \\ University, Cairo, Egypt. \\ ${ }^{2}$ Computer Science Department, College of Computer and Information Sciences, Princess Nourah Bint Abdulrahman \\ University, Riyadh, Saudi Arabia. \\ E-mail: saismail@pnu.edu.sa, sahar.hassan@feng.bu.edu.eg
}

\author{
Sahar S. Shabanah ${ }^{2,3}$ \\ ${ }^{3}$ Computer Science Department, Faculty of Computing and Information Technology, Jeddah, Saudi Arabia. \\ E-mail: ssshabanah@pnu.edu.sa,sshabana@kau.edu.sa
}

\begin{abstract}
Accreditation is considered as one of the major aspects of ABET, where educational institutions continuously develop the quality of academic programs to achieve it. For the most part of this continuous development needs, the programs determine definite and measured objectives for their students, evaluate their efforts to achieve these objectives, and amend their programs based on the results of that assessment. In addition to providing educational institutions an organized strategy to appraise and develop their programs. The primary focal point to prepare for accreditation is the learning objectives and program outcomes assessment. So, College of Computer and information Sciences (CCIS) at Princess Nourah Bint Abdulrahman (PNU) needs to fulfill ABET criteria to achieve the outcomes. So, CCIS need a system to achieve course assessment matrix without wasting the time and efforts. This system will help the staff members in identifying student learning objectives that are expected to achieve as well as to identify assessment tools and evaluation feedback for each topic. This paper describes Course and Student Management System (CSMS) established to address a course assessment matrix, and help achieve departmentstated objectives. Whereas, CSMS is a web based system provides many features to facilitate the creation of articulation matrix, course assessment based on students learning objectives, the student's evaluation and tracking attendance of students. This system is considered as a new method of creating the course assessment matrix that will help the department head, instructors and course coordinator. It is user friendly and interactive interface, saving the time and efforts.
\end{abstract}

Index Terms-ABET, Accreditation, Articulation Matrix, Course Assessment Matrix, Learning Objectives, Program Outcomes, Web Based.

\section{INTRODUCTION}

ABET is a United State association, it was established in 1932 as the Engineers' Council for Professional Development (ECPD), a professional body of engineering in the USA, devoted to the engineering professionals \& students' development, education, regulation, and accreditation. It was headquartered in New York, in the building of Engineering Societies, then in the United Engineering Center. In 1996, it transferred to Baltimore [1][2][3].

In order being quality minded in higher education means caring about the expectations of scholars and other customers as well as all involved parties. ABET requirements for accreditation changed in many ways. New accreditation rules need evidence that computing students acquire a liberal education that extends beyond traditional computing topics and includes areas such as teamwork, ethics, lifelong learning, oral communication, and an awareness of the impact of computing on society to name just a few. ABET also requires a procedure for continuous assessment and improvement of the educational program [4][5][6].

Some universities apply ABET criteria on their academic programs to achieve ABET accreditation. It is considered as an evaluation process that needs from programs to induce an overall periodically assessment of all academic actions. The continuous evaluation of education quality is the most significant factor to be accredited by ABET, This process depends on asses curriculum, teaching staff efficiency, students' level and many other elements. The weak rate of success is caused due to [3][7]:

- Widely, Computing Programs are new and they are investigating accreditation for the first time.

- Staff experience in Computing Program accreditation is rare.

- $\quad$ The Computing discipline boundaries are still.

\section{BACKGROUND INFORMATION}

ABET is an accrediting association that accredits 
various educational programs such as computing, engineering, technology and applied science. ABET supports innovation and quality in education [8][9].

The accreditation awarding implies that the education of accredited program has met standards, and is willing to improve its academic program by performing the recommendations in the report of accreditation. The accreditation value is a professional pride for the staff and the gratification of teaching an accredited program course [9][11].

The accreditation is valuable not only to the institution and its staff, but as well to the students [8][9][10][11]. Students are most affected by accreditation since they are the key focus of the educational process. Accreditation assures them that their demands are being gathered through a quality educational program and that their preparation reaches high levels. It also reassures them that prestigious institutions will most likely have their transfer credits and their degree will be a tool for getting a right job and for personal development. The accreditation also increases their trust in their educational program and staff, and their attitude toward academic work [9][10][11].

CCIS Programs (Computer Science, Information System, and Communication Systems \& Networking) accreditation indicates the students that educates in the program will enter the profession. The criteria of ABET are built up by professionals from both education and industry. This allows the education to meet the needs of the computing labor market, eventually students' preparation for more success.

\section{A. ABET General Criterion}

After investigating evaluating academic programs in previous years, eight general criteria were approved by the ABET agency for computing program accreditation. These criteria should be satisfied by any accredited computing program. The criteria of the program comprise various topics related to information technology curriculum [1][2][3][8].

ABET Computing program criteria apply to computer science, Information Technology or similar terminology and Table 1 presents the ABET criteria for the Computing programs [12].

\section{B. Learning Assessment}

The assessment concept means the procedures that used to identify, gather, and analyze to measure the acquisition of course learning outcomes and the objectives of the program. The assessment to be efficacious, it uses relevant, qualitative, quantitative, indirect and direct measures to evaluate the outcomes or objectives. There has been a considerable debate (and confusion) in the ABET community about indirect and direct assessments [4][13][14].

1) Direct and Indirect Assessments: Some possible tools of program level and course level assessment (indirect and direct) are presented in Table 2 [13][14].
- Direct measures (assessments) reflect the students' knowledge or their skills versus measurable learning outcomes.

- Indirect measures (assessments) are those that ascertain the opinion or self-report of the value or extent of learning experiences.

2) Summative and Formative Assessments: Summative assessment is the most practiced types of assessment. It is used to recognize that if the students have attained learning objectives, following the completion of learning activities. It is as an assessment of learning and briefed the learners' development at a specific time. Formative assessment measures the student development through the educational process and also, it is carried out to make any required modifications. It provides information to the student about strengths, progress, and areas of improvement [3][13][14].

- The main variation between summative and formative assessment is that the primary aim in formative assessment is to inform the faculty member about the students' weak points and to take into account for the instruction adjustments derived from the students' performance. But at the end of learning, summative assessment happens, which indicates that it has less impact on the students learning [3][4][13][14].

Student learning outcomes assessment has a significant part in educational efficacy, sustainability, and perfection, where it is more and more being known and wanted by accrediting organizations [14][15]. The assessment process is considered as an inbuilt component of ensuring that an educational institution meets prerequisite standards, as considerably as a pivotal way of furnishing the evidences needful for searching and preserving accreditation. The accomplishment of each objective outcomes and outcome of the program is at the assessment procedure focus. Assessment purposes as follows [16]:

- Improve student learning and achievement.

- Provide a helpful executive data which accelerate to take the decision.

- Suggestions are made for improving teaching effectiveness.

- Review, improve and evaluate the strength of various teaching strategies.

- Identify students' strengths and failings.

- Ability to communicate with internal and external stakeholders.

- Review, evaluate, and improve the effectiveness of curricular plans. 
Table 1. ABET Computing Program Criterion [1][2][3]

\begin{tabular}{|c|c|}
\hline Curriculum & $\begin{array}{l}\text { Students have the following amounts of course work } \\
\text { or equivalent educational experience: } \\
\text { a. Computer science: One and one-third years that } \\
\text { includes: } \\
\text { 1. Coverage of the fundamentals of algorithms, } \\
\text { data structures, software design, concepts of } \\
\text { programming languages and computer } \\
\text { organization and architecture. } \\
\text { 2. An exposure to a variety of programming } \\
\text { languages and systems. } \\
\text { 3. Proficiency in at least one higher-level } \\
\text { language. } \\
\text { 4. Advanced course work that builds on the } \\
\text { fundamental course work to provide depth. } \\
\text { b. One year of science and mathematics: } \\
\text { 1. Mathematics: At least one half year that } \\
\text { must include discrete mathematics. The } \\
\text { additional mathematics might consist of } \\
\text { courses in areas such as calculus, linear } \\
\text { algebra, numerical methods, probability, } \\
\text { statistics, number theory, geometry, or } \\
\text { symbolic logic. } \\
\text { 2. Science: A science component that develops } \\
\text { an understanding of the scientific method } \\
\text { and provides students with an opportunity to } \\
\text { experience this mode of inquiry in courses } \\
\text { for science or engineering majors that } \\
\text { provide some exposure to laboratory work. }\end{array}$ \\
\hline $\begin{array}{l}\text { Program } \\
\text { Outcomes }\end{array}$ & $\begin{array}{l}\text { The program enables students to achieve, by the time } \\
\text { of graduation: } \\
\text { (j) An ability to apply mathematical foundations, } \\
\text { algorithmic principles, and computer science } \\
\text { theory in the modeling and design of computer- } \\
\text { based systems in a way that demonstrates } \\
\text { comprehension of the tradeoffs involved in design } \\
\text { choices. } \\
\text { (k) An ability to apply design and development } \\
\text { principles in the construction of software systems } \\
\text { of varying complexity. }\end{array}$ \\
\hline $\begin{array}{c}\text { Faculty } \\
\text { Qualifications }\end{array}$ & Some full time faculty members have a Ph.D. \\
\hline
\end{tabular}

Table 2. Direct and Indirect Assessment Methods

\begin{tabular}{|l|l|}
\hline Indirect Assessment Methods & Direct Assessment Methods \\
\hline Exit and other interviews & Simulations \\
\hline Archival records & Behavioral observations \\
\hline Focus groups & Performance Appraisal \\
\hline $\begin{array}{l}\text { Written surveys and } \\
\text { questionnaires }\end{array}$ & Locally developed exams \\
\hline & External examiner \\
\hline & Portfolios \\
\hline & Oral exams \\
\hline & Standardized exams \\
\hline
\end{tabular}

\section{Learning Objectives or Outcomes}

The foremost point in specifying a curriculum or course is the improvement of learning objectives, at times called learning outcomes. Where they are statements of noticeable students' acts which they provide the evidences of the skills, attitudes, and knowledge gained from the curriculum. Various capabilities identified in one outcome which it would commonly entail several assessment measurements [6][13].

Student Learning Objectives (see Table 3) represent what a student has expected to be educated and became qualified for doing by the graduation period. They indicate the behaviors and skills which students will gain through the course of study. Some of the outcomes in core courses have to map onto or be similar together with at least one from program learning outcomes. Students learning outcomes must be determined in order to the staff have a popular conception of the probabilities for students' education and to fulfill uniformity towards the curriculum, when measured by the indicators of performance. Where the indicators of performance describe the attitudes, skills and behavior of the students must be able to demonstrate by the period of graduation that represent adequacy regarding to the outcomes $[2][4][5][[13]$.

Table 3. Student Outcomes for Computing Programs [2][4][5][[13]

\begin{tabular}{|c|c|c|}
\hline $\begin{array}{c}\text { COMPUTER } \\
\text { SCIENCE }\end{array}$ & $\begin{array}{c}\text { INFORMATION } \\
\text { SYSTEMS }\end{array}$ & $\begin{array}{c}\text { INFORMATION } \\
\text { TECHNOLOGY }\end{array}$ \\
\hline
\end{tabular}

a) An ability to apply knowledge of computing and mathematics appropriate to the discipline.

b) An ability to analyze a problem, and identify and define the computing requirements appropriate to its solution.

c) An ability to design, implement, and evaluate a computer-based system, process, component, or program to meet desired needs.

d) An ability to function effectively on teams to accomplish a common goal.

e) An understanding of professional, ethical, legal, security and social issues and responsibilities

f) An ability to communicate effectively with a range of audiences.

g) An ability to analyze the local and global impact of computing on individuals, organizations, and society.

h) Recognition of the need for and an ability to engage in continuing professional development.

i) An ability to use current techniques, skills, and tools necessary for computing practice.

\begin{tabular}{|c|c|c|}
\hline $\begin{array}{l}\text { (j) An ability to } \\
\text { apply } \\
\text { mathematical } \\
\text { foundations, } \\
\text { algorithmic } \\
\text { principles, and } \\
\text { computer science }\end{array}$ & \multirow{3}{*}{$\begin{array}{l}\text { (j) An } \\
\text { understanding of } \\
\text { processes that } \\
\text { support the } \\
\text { delivery and } \\
\text { management of } \\
\text { information } \\
\text { systems within a } \\
\text { specific } \\
\text { application } \\
\text { environment. }\end{array}$} & $\begin{array}{l}\text { (j) An ability to use and } \\
\text { apply current technical } \\
\text { concepts and practices in } \\
\text { the core information } \\
\text { technologies. }\end{array}$ \\
\hline \multirow{2}{*}{$\begin{array}{l}\text { (k) An ability to } \\
\text { apply design and } \\
\text { development } \\
\text { principles in the } \\
\text { construction of } \\
\text { software systems } \\
\text { of varying } \\
\text { complexity. }\end{array}$} & & $\begin{array}{l}\text { (k) An ability to identify } \\
\text { and analyze user needs and } \\
\text { consider them in the } \\
\text { selection, creation, } \\
\text { evaluation and } \\
\text { administration of computer- } \\
\text { based systems. }\end{array}$ \\
\hline & & $\begin{array}{l}\text { (1) An ability of effectively } \\
\text { integrate } \Pi \text {-based solutions } \\
\text { into the user environment. }\end{array}$ \\
\hline
\end{tabular}

\section{Course Assessment or Articulation Matrix}

The course assessment matrix, sometimes called articulation matrix (see Fig. 1), contains a group of rows that represent learning objectives, a group of columns which represent class activities and a group of letters indicating the Levels of Learning effect, where for each learning objective, one or more activity has been assigned to it. The articulation matrix is filled, when the course learning objectives have been developed [17][18][19].

While the articulation matrices are not directly concerned with students' evaluation, they support in two 
areas of assessment. Foremost, they can be used to preevaluate the courses to see if these courses hold the prospective of the wanted targets. One more, the assessment tools for various class activities are selected according to the courses matrices. Later all the activities of each course have been entered and their impact entered in the matrix, then it can be assessed to emphasize that the suggested course is perfect and has the potential to permit students to acquire the predetermined learning objectives [14][17].

While the articulation matrix has a broader application, the most two applications are, that the matrix is used in course articulation, and another it has been used as part of the process of ABET accreditation [17].

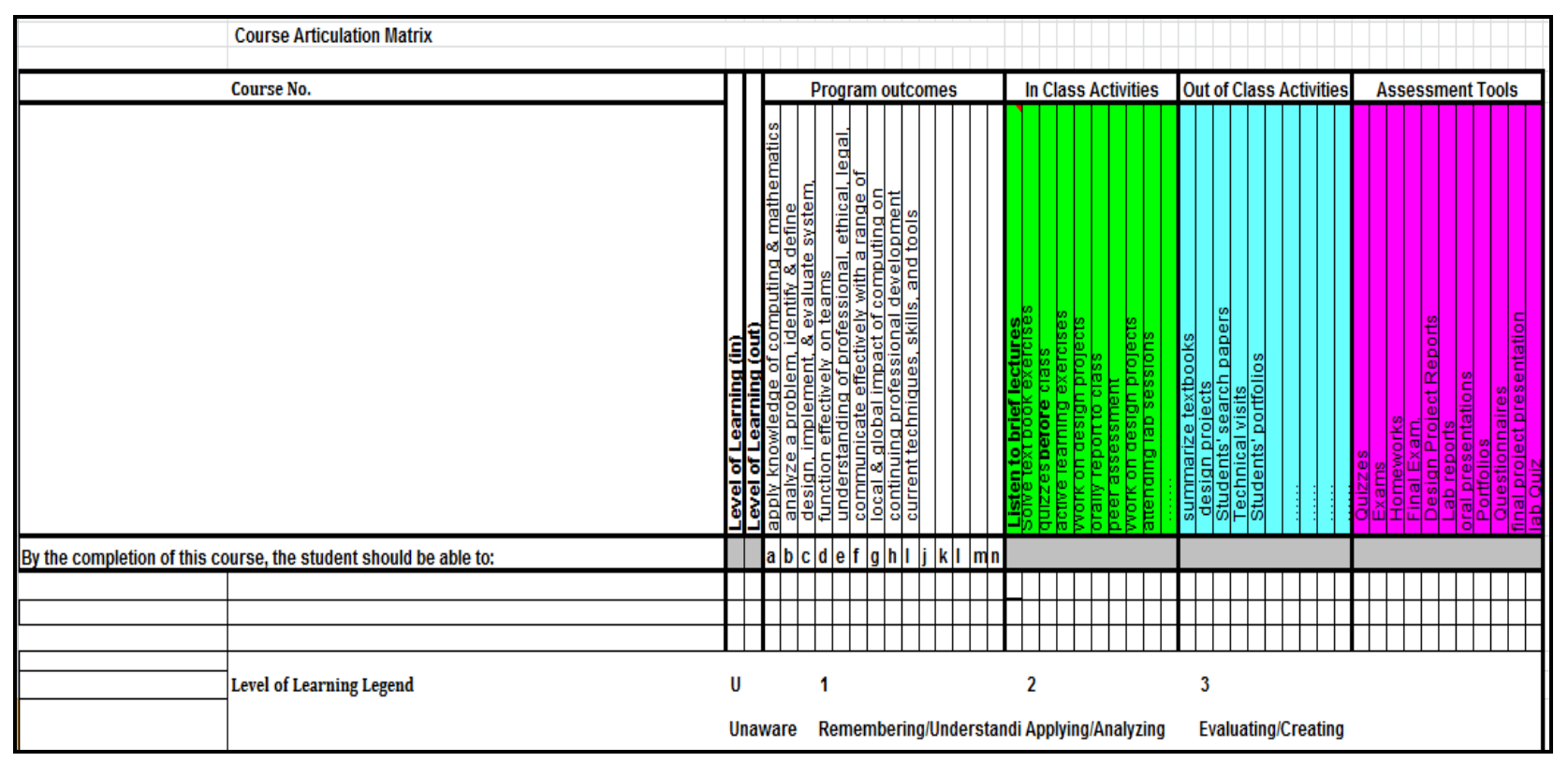

Fig.1. An Articulation Matrix

\section{PROPOSED SOLUTION}

It is significant to attain assured that, program outcomes, performance measurements, and enforcement strategies integrated. One advantage of getting an assessment scheme is that the improvement procedures itself, where permits the staff to check the full syllabus and to rate each course, how to be fitted into the program outcomes [20].

Developing a course to attain specific learning objectives, needs great efforts in different domains definitely three as indicated in Fig. 2. These domains include the learning objectives, instructions and assessments [6][13].

For each course, A number of learning objectives should be determined. Where, a learning objective is a declaration of a noticeable student's action which presents an evidence of skills and/or attitudes gained in the course. This learning objective should include a verb of an observable action, such as (calculate, design ...) to be permitted as an objective of learning [14][17][18][21].

An articulation or a course assessment matrix is created by using vertical lines for the outcomes of the program, and horizontal lines for the learning objectives of the course. Put for each learning objective an impact value in the matrix to show how the program outcome is addressed by the course learning objective where the values as a consequence are 1, 2, or 3 that mean marginally, moderately, or substantially. The inputs must consider a harmony of all staff members that are to be expected to educate the course.

The proposed solution for this problem is to develop a web-based system that helps CCIS to achieve the criteria easier and faster. The system is concerning course outcomes and assessment of each topic in the course, that will depend on the program outcomes achieves. It helps faculty and administration to avoid delays and loss of time and effort required to build matrix, reports, and course specifications. Storing a huge amount of data and correct information, leading to build a knowledge base helps in decision-making, the ability to save data and information entered and easy information retrieval. The system aims to create a course assessment matrix and help faculty to assess students in easiest way.

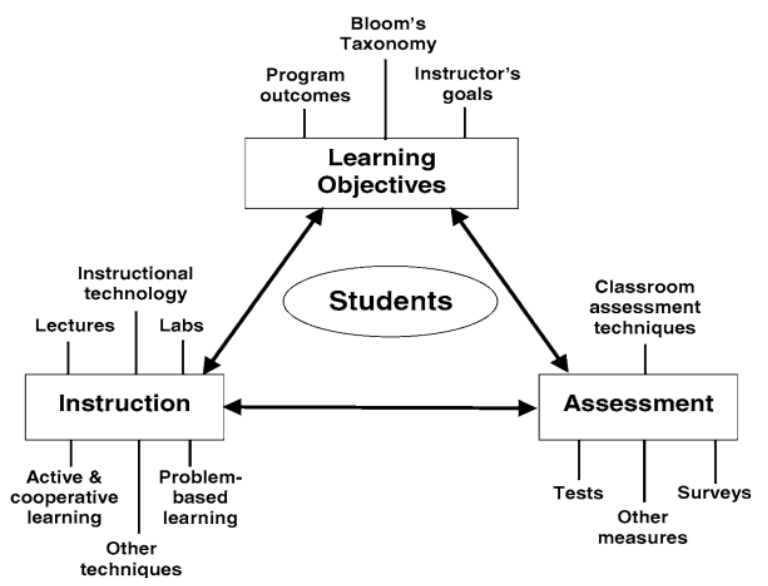

Fig.2. Elements of course design [6][13]. 


\section{SYSTEM ANALYSIS AND DESIGN}

In the proposed system, there are three agents Head of Department, Instructor and Course Coordinator simply Coordinator (Admin). CSMS Entity Relationship Diagram (ERD) indicated in Fig. 3-a, and Context diagram for the system as shown in Fig. 3-b that interacts with 3 agents. Use case diagram of CSMS shown in Fig. 3-c and the System Architecture indicated in Fig. 4.

There are a number of programming languages and software tools that used to build the proposed system comprise ASP.NET, Visual Basic and SQL server were used to build the system database, design the screens. In Fig. 5 and Fig. 6 show the main input and output screens of CSMS.

\section{RESUlT AND DISCUSSION}

Unit testing, functional testing and user acceptance testing were applied. Testing was applied for three kinds of users that Head of Department, Course Coordinator
(Admin), and Instructor. The system works as expected; testing proved that CSMS (version 1.0) system is easy to use for users with different responsibilities. Also, it is user friendly with high usability for beginners with few technical skills. CSMS is ready to be deployed. It is menu driven and provides informational and error messages to help the users to direct through various options. For Security, each user will need a user ID and Password to login the system. The system provides forms to change password for all users. Also, it allows users to manage courses, evaluate every topic, course and learning objective, the instructor can control student's marks, tracking attendance of students and many other features as listed below. The results showed that the majority of users tested, who agreed that completing CSMS was quick, also agreed that they would use the CSMS system.

\section{A. CSMS Features}

Course and Student Management System involves the features that indicated in Table 4.

Table 4. Course And Student Management System Features

\begin{tabular}{|c|c|}
\hline $\begin{array}{l}\text { Head of } \\
\text { Department }\end{array}$ & $\begin{array}{l}\text { - Log In and Log Out. } \\
\text { - Update Head of Department Personal Information. } \\
\text { - View (Coordinator, Instructors, and Courses). }\end{array}$ \\
\hline Coordinator & $\begin{array}{l}\text { - Log In and Log Out. } \\
\text { - Update Coordinator Personal Information. } \\
\text { - Users Control (Add users, Search user, Select User Role, Activate and Deactivate users, Delete user). } \\
\text { - Course Control (Add Course, Edit Course Name and Number, Delete Course, Search Course). } \\
\text { - Assessment Tools (Add Tools, Edit Tool Name and Type, Delete Tools, Save Tools). } \\
\text { - In class Activities (Add Activity and its Description, Edit Activity Name and Description, Delete Activity, Save Activity). } \\
\text { - Out Class Activities (Add Activity and its Description, Edit Activity Name and Description, Delete Activity, Save Activity). } \\
\text { - Program Outcomes (Choose Department, Add Outcomes, Edit Outcomes, Delete Outcomes, Save Outcomes). } \\
\text { - Instructor Courses (Choose Department, Choose Level, Choose Course, Add Course to Instructor Schedule, Edit Course } \\
\text { Name and Number, Delete Course, Save Course). } \\
\text { - Instructors Control (Add Instructor, Search user, Select User Role, Activate and Deactivate users, Delete user). } \\
\text { - Contacts (Read message "Convert message color from red to green”, Delete message). }\end{array}$ \\
\hline Instructor & $\begin{array}{l}\text { - Log in and log out. } \\
\text { - Update Instructor personal information. } \\
\text { - Topics Control (Choose Course, Add Topics, Edit Topics, Delete Topics, Save Topics). } \\
\text { Outcomes, Larning Objectives (Choose Course, Choose Topic, Add Course Learning Outcomes, Edit Outcomes, Delete } \\
\text { - Evaluation View (Choose Level and Course, View Evaluation). } \\
\text { - Grades Sheet (Choose Year and Course, View Grades Sheet, Add Student Name, Add Mark, Save). } \\
\text { - Course matrix (Choose Year and Course, View Course matrix). } \\
\text { - Search Student (Search Students by Student Name, Edit Student Information, Delete Student, Save). } \\
\text { - Students Weekly Marks (Enter Year And Semester, Select Topic, Student Name, Week, Lecture No., Check Attendance, } \\
\text { Add Attendance) } \\
\text { - Students Total Marks (Open Weekly Marks Page, Select Topic, Student Name, Week, Route, Add Mark, Delete Mark, } \\
\text { Save). } \\
\text { - View Student Marks (View Student Marks By Selecting Topic and Student Name). } \\
\text { - Course Marks Matrix (View). }\end{array}$ \\
\hline $\begin{array}{l}\text { Admission of } \\
\text { Users }\end{array}$ & $\begin{array}{l}\text { - CSMS provides online registration and status information to the user to view their application status. } \\
\text { - CSMS provides an automatic user register generated number based on course and year. }\end{array}$ \\
\hline $\begin{array}{l}\text { Management } \\
\text { of Student } \\
\text { Attendance }\end{array}$ & - Easily add and track attendance of students. \\
\hline Security & - Registered users have a Login ID and Password. \\
\hline Usability & $\begin{array}{l}\text { - The Graphic User Interface (GUI) of the system is user-friendly. } \\
\text { - The GUI of the system presents conceptual integrity. }\end{array}$ \\
\hline
\end{tabular}




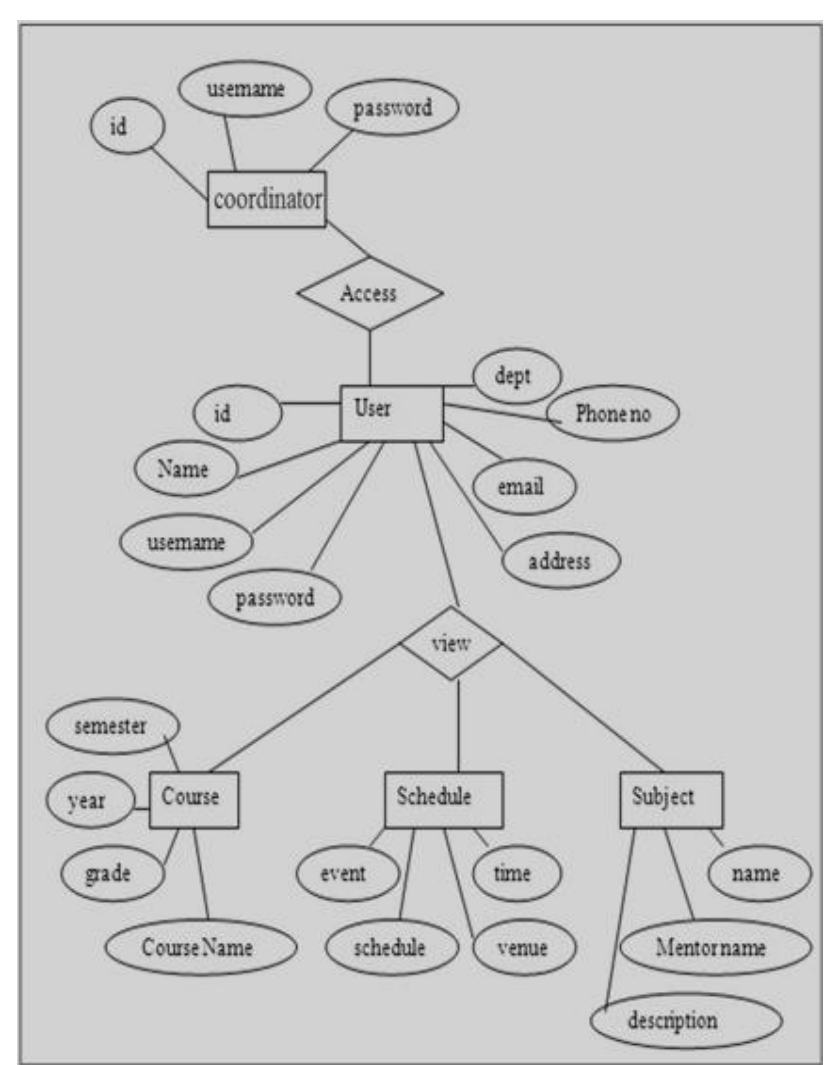

(a) Proposed system ER Diagram

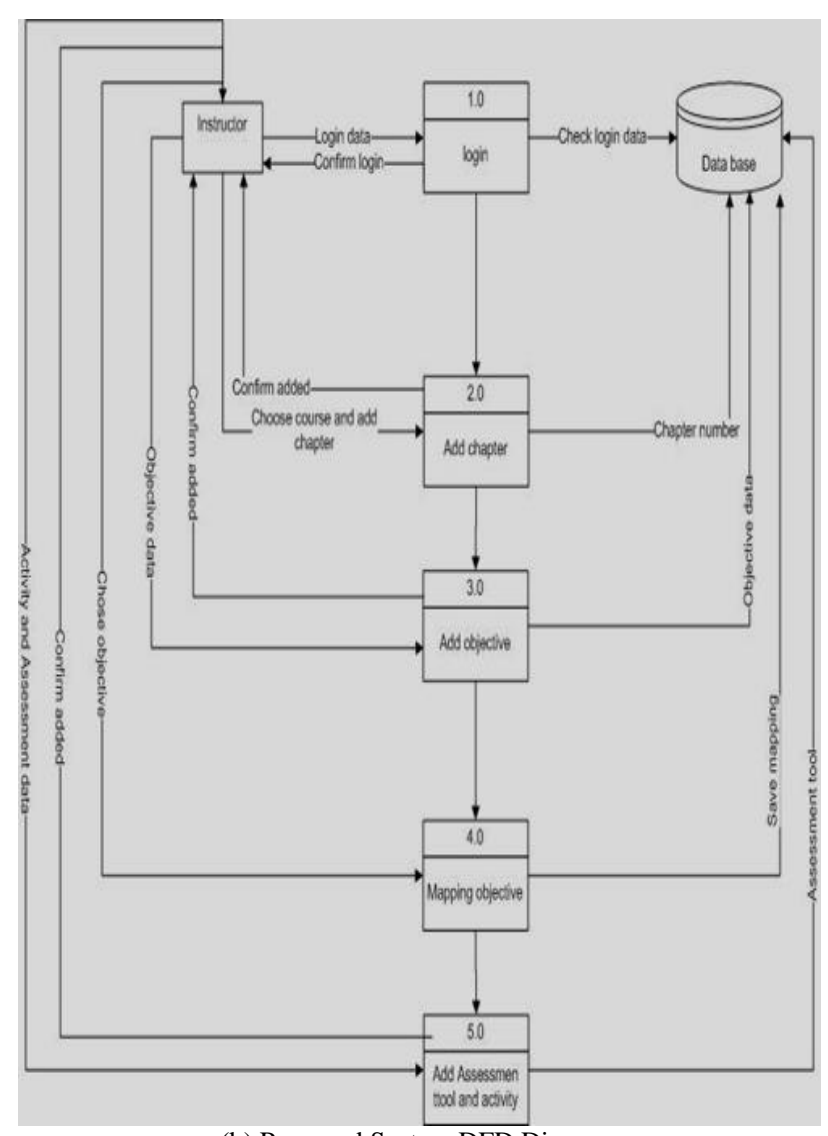

(b) Proposed System DFD Diagram

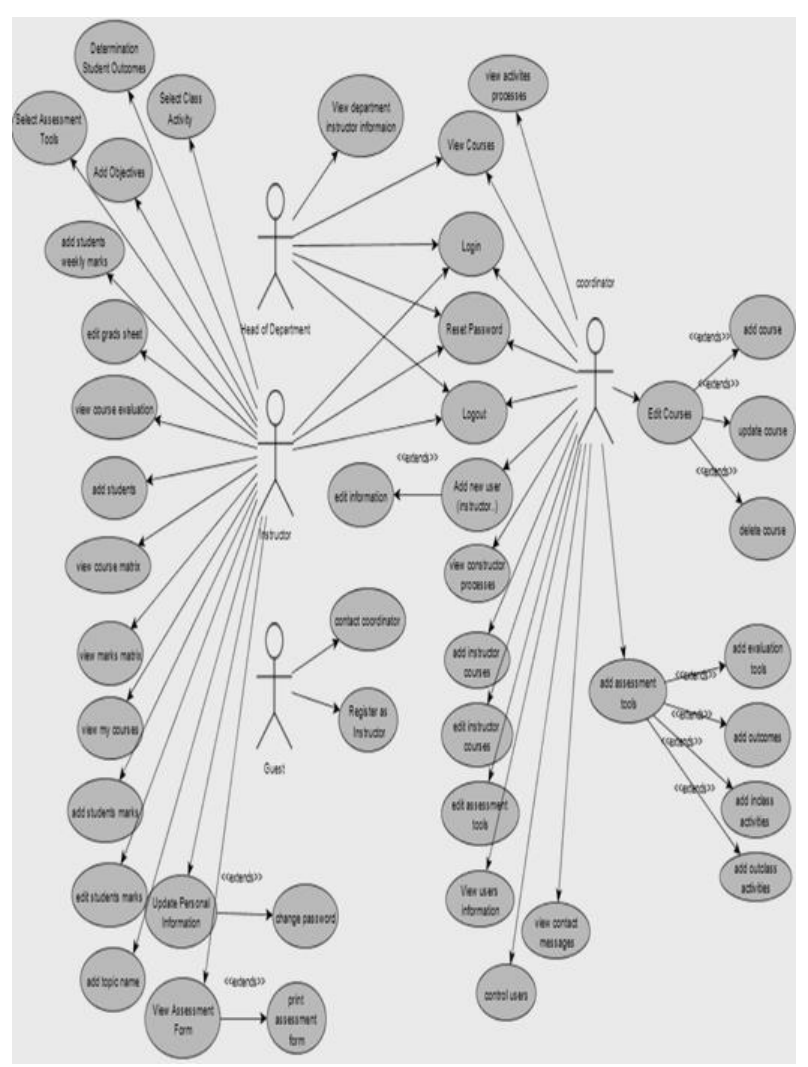

(c) Use Case Diagram

Fig.3. CSMS System Diagrams

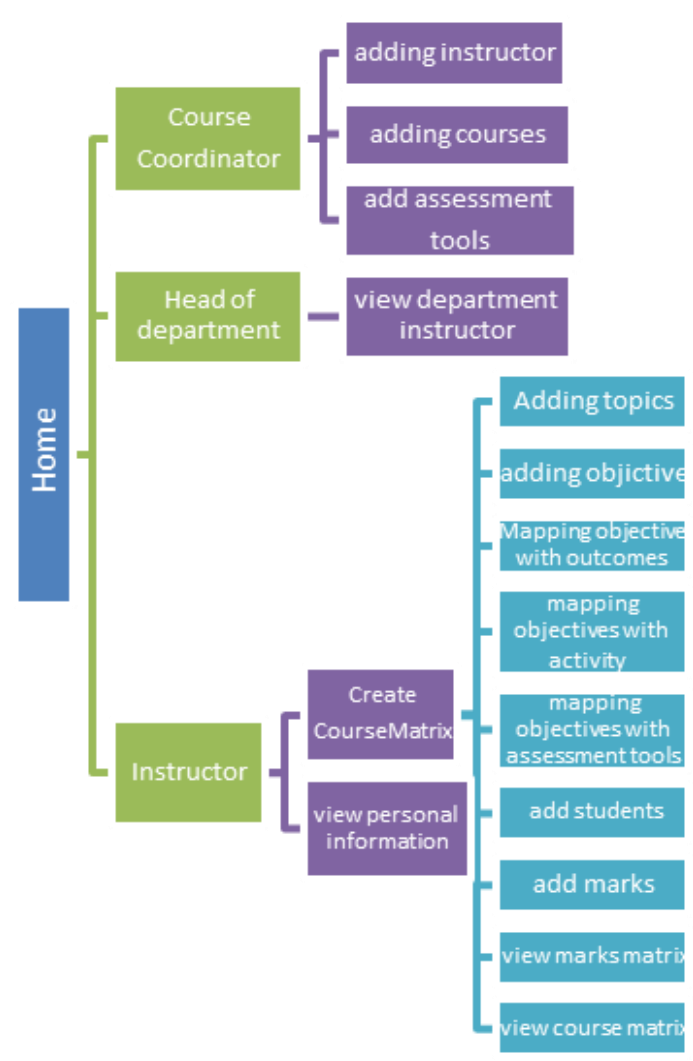

Fig.4. CSMS System Architecture 


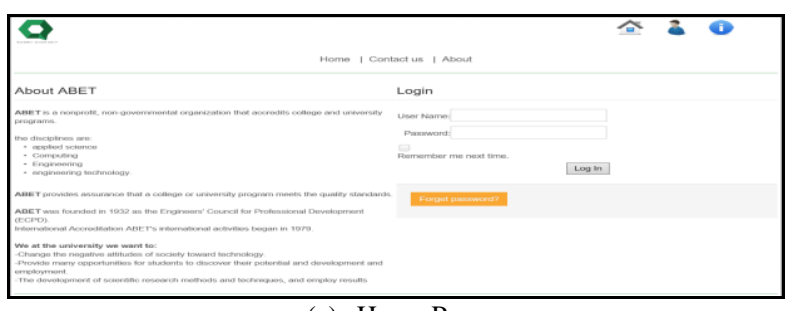

(a) Home Page

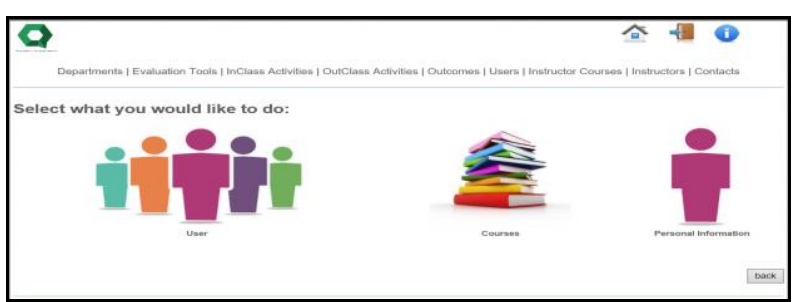

(c) Course Coordinator Control Panel

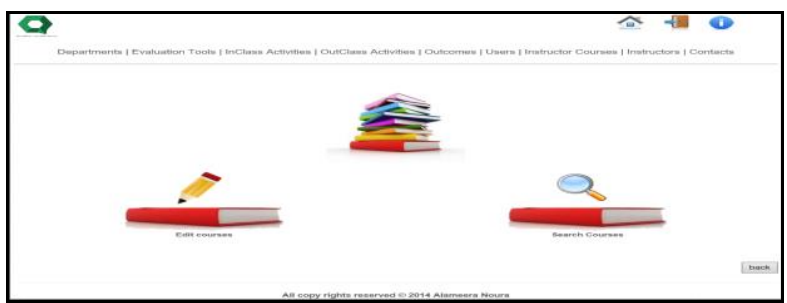

(e) Control Courses Page

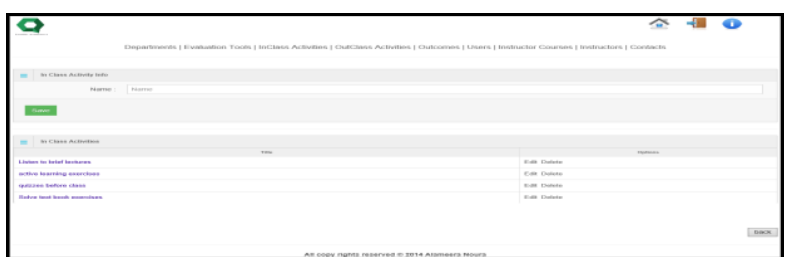

(g) In Class Activates Page

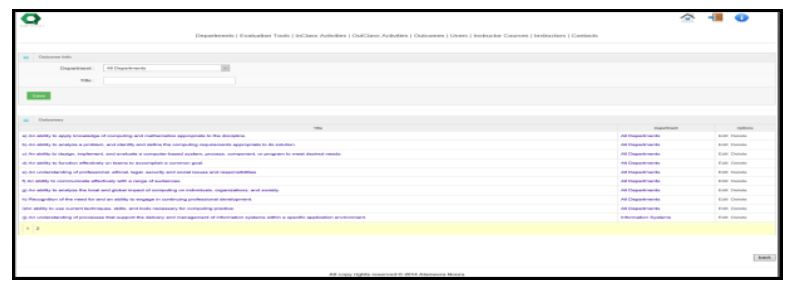

(i) Outcomes Page

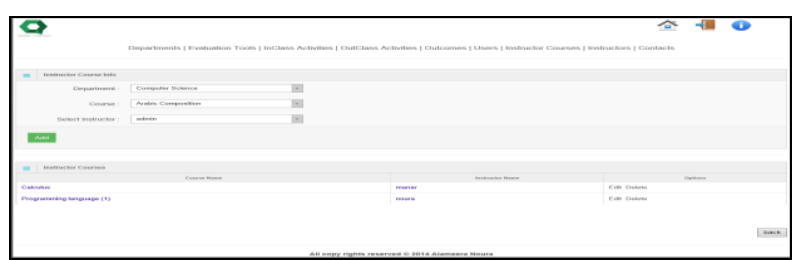

(k) Instructor's Courses Page

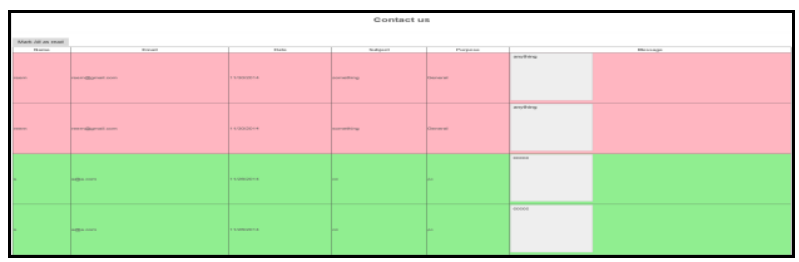

(m) Contact Control Page

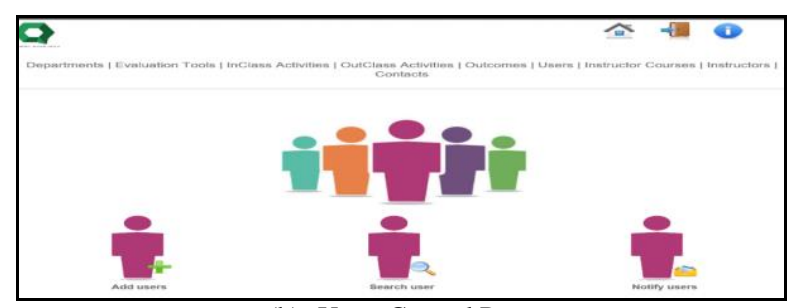

(b) Users Control Page

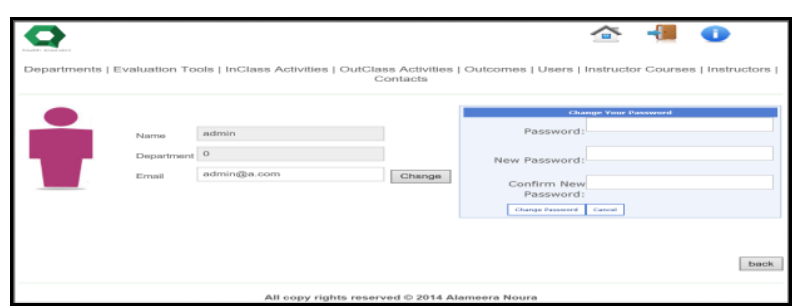

(d) Course Coordinator Personal Information

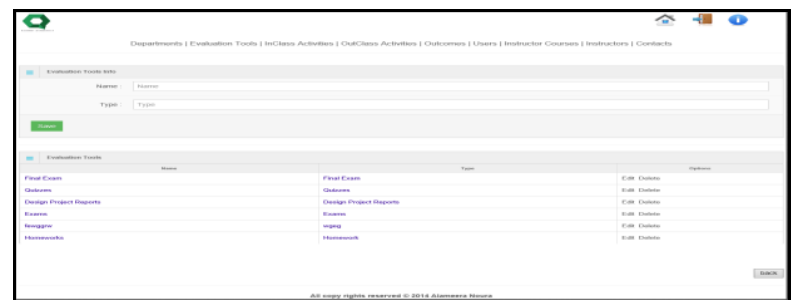

(f) Evaluation Tools Page

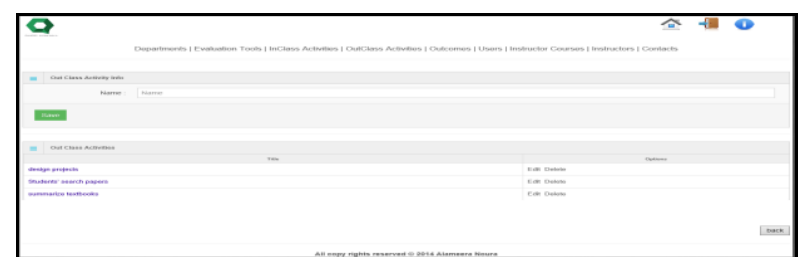

(h) Outclass Activates Page

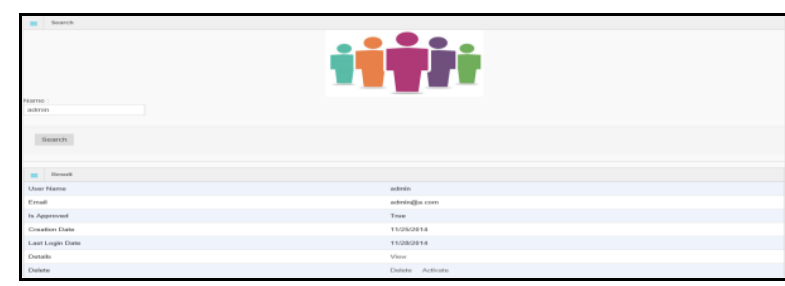

(j) Search User Page

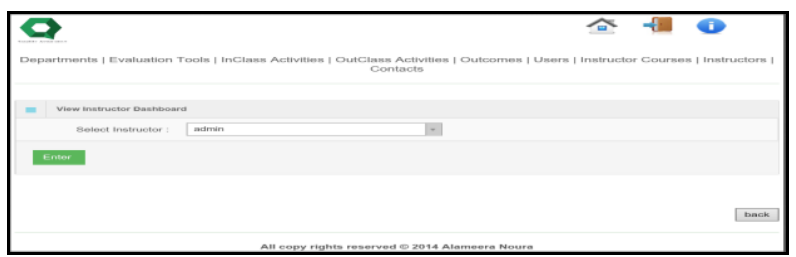

(1) Instructor Dashboard

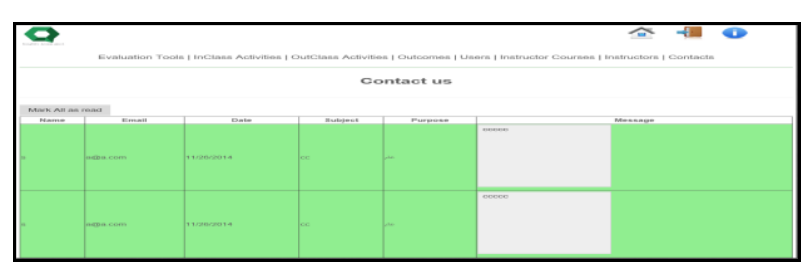

(n) The System Will Change Unread Messages From A Pink Color To Green.

Fig.5. Main Course Coordinator (Administrator) Screens 


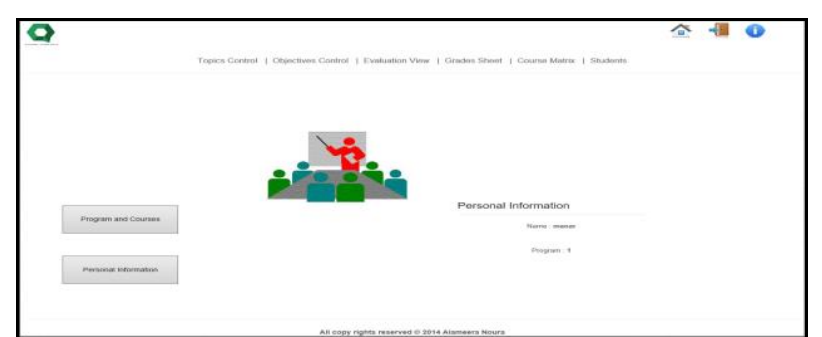

(a) Instructor Control Panel

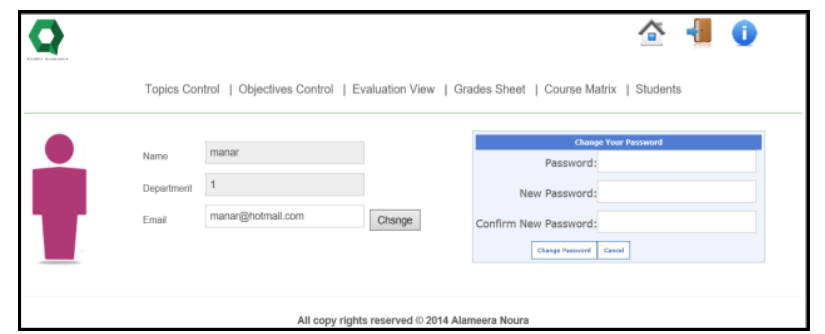

(c) Personal Information (Instructor)

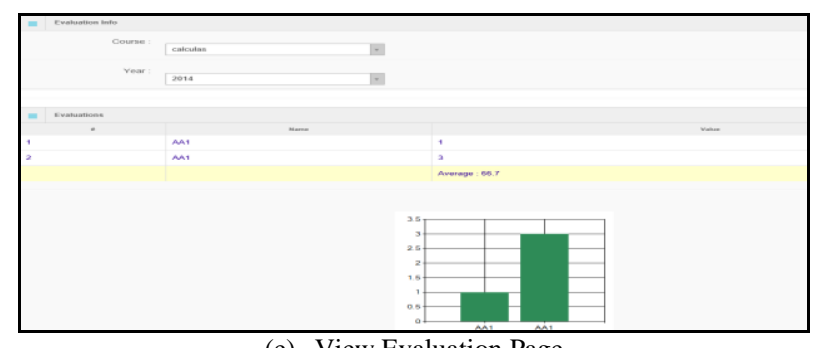

(e) View Evaluation Page

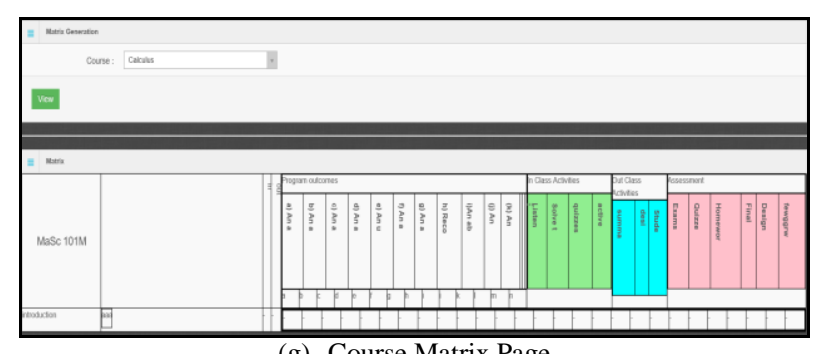

(g) Course Matrix Page

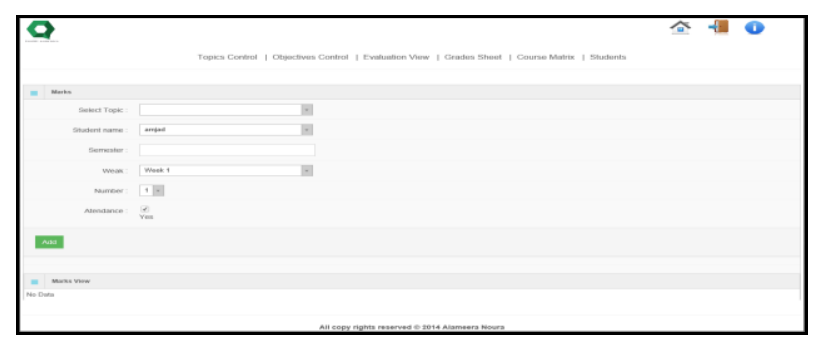

(i) Weekly Marks Page

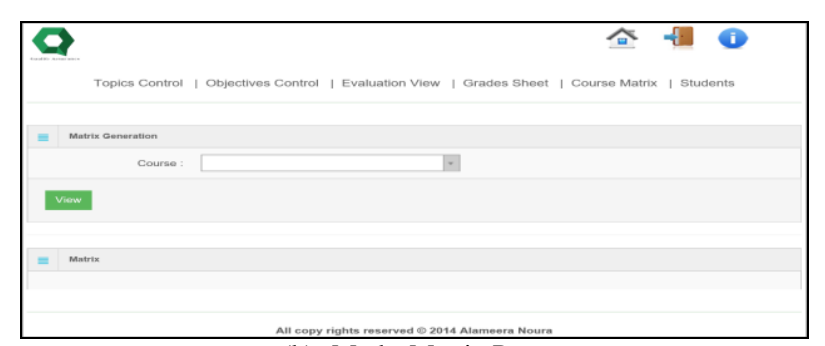

(k) Marks Matrix Page

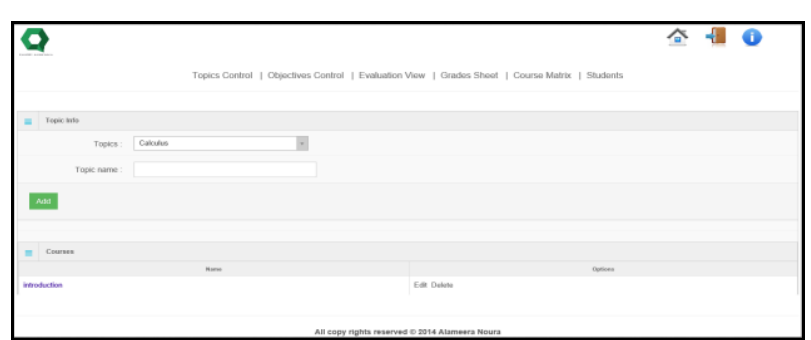

(b) Topic Control Page

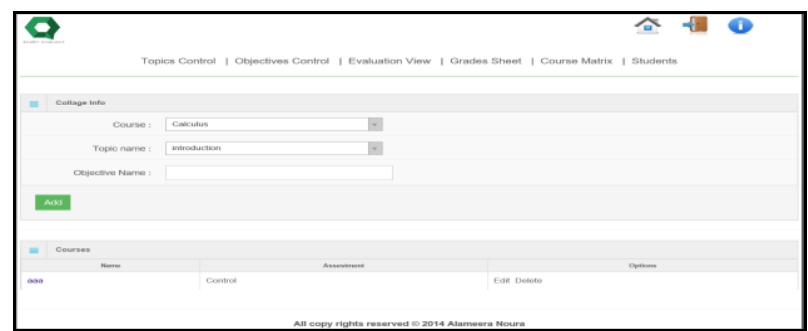

(d) Learning Objectives Page

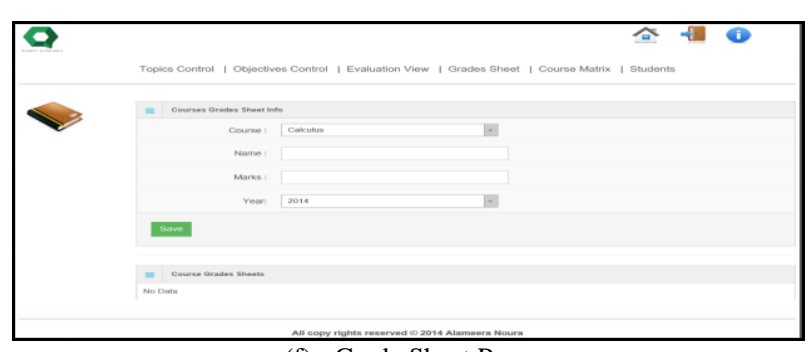

(f) Grade Sheet Page

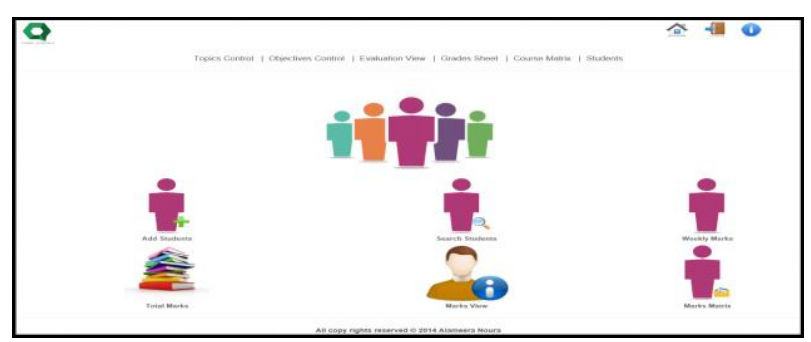

(h) Students Page

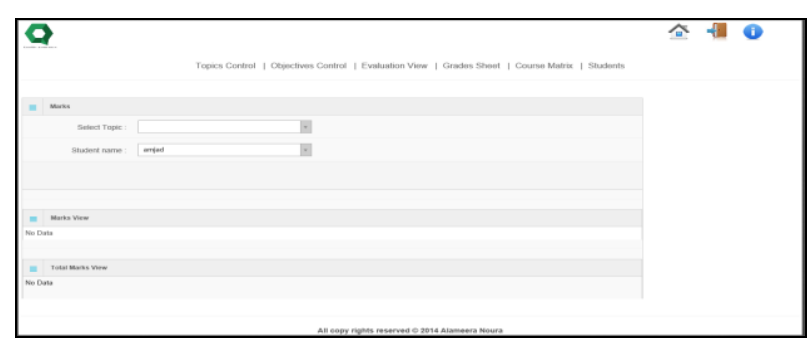

(j) View Marks Page

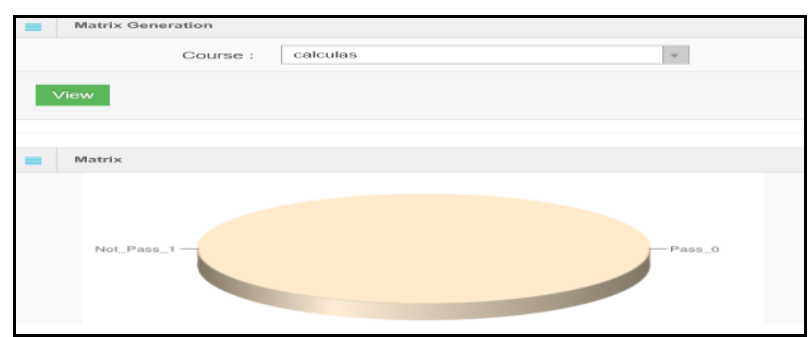

(1) Grading Report

Fig.6. Main Instructor Screens 


\section{FUTURE WORK}

In the nearest future, some features will be added to become available to all engineering and computing programs such as:

- Creating program assessment matrix.

- Connecting CSMS website with PNU admission and registration system.

- Examination Management whereas, CSMS will provide a comprehensive exam scheduling based on the courses.

- Apply the Arabic language to the system besides the English language to create Arabic courses matrices.

- $\quad$ Exporting data and reports to Excel files.

Provide a calendar for users, where it contains reminders, memos, important days, etc.

\section{CONCLUSION}

Accreditation helps students and their parents choose between the accredited programs, enable employers and high schools to enroll graduates that are recognized a skillfully- prepared, and are used by the certification boards to screen applicants. The proposed system (CSMS) achieves an active solution for the main challenge in the accreditation in higher education institutions which is creating a course assessment matrix and therefore, assessment of the course and program. Students, curriculum, faculty and resources are accessible, as stated in the standards, to fulfill the learning objectives. CCIS needs to fulfill ABET criteria to achieve the outcomes. There are some colleges in different universities using Excel Sheets to make course assessment matrix, which is wasting time and efforts. We believe that computer science educators have the creativity and intellectual prediction to become good course assessors. The course assessment matrix provides some structure as they start the exploring process by studying all possibilities for efficient assessment. The matrix was created to warrant the most flexibility in the selection of outcomes, activities, assessment tools, impact and findings. Whereas, concurrently ensuring that all main components of the assessment process is taken into consideration. Our prospect is that staff will utilize it as a useful system to develop the courses, study and assessment plans. CSMS is very useful, especially in converting the course assessment matrix from excel sheet to a web based system that can help the faculty to create her/his course assessment matrix in an easy way. This system will help faculty members in identifying courses and student outcomes that are expected to achieve as well as to identify methods of assessment and evaluation of results. Therefore, the education process is improved and developed, accordingly, help students and parents to choose the suitable program, which provide high quality education and help graduates to work in the labor market.

\section{ACKNOWLEDGMENT}

The authors extend their sincere thanks to everyone involved in the CSMS system at CCIS-PNU, especially for Amjad F. ALRusayes, Anfal A. AL-Nassir, Maram M. AL-Shamari, Nouf K. AL-Subaei, Hadeel S. AL-Shabeeb.

\section{REFERENCES}

[1] Al-Bakry, A. M., "E-Assessment System based on ABET criterion for Computing Programs", Journal of Babylon University, Pure and Applied Sciences, Vol. 22, No.5, pp 1482-1489, 2014.

[2] Abet.org, (n.d.), "ABET", [online] Available at: http://www.abet.org/webinar.shtml/ [Accessed 13 Aug. 2014].

[3] Goda, B. S. \& Reynolds, Ch., "Improving Outcome Assessment in Information Technology Program Accreditation", Journal of Information Technology Education: Innovations in Practice, Vol. 9, pp IIP-50 IIP-59, 2010.

[4] Abet.org, (n.d.), “ABET - Assessment Planning”, [online] Available at: http://www.abet.org/assessment-planning/ [Accessed 16 Sep. 2014].

[5] Abet.org, "ABET - What Kinds of Programs Does ABET Accredit?”, 2014 [online] Available at: /http://www.abet.org/types-of-programs-abet-accredits/

[6] Fatima, S. \& Abdullah, S., "Improving Teaching Methodology in System Analysis and Design using Problem Based Learning for ABET", International Journal of Modern Education and Computer Science (IJMECS), 5(7), pp.60-68, 2013. http://www.mecs-press.org/

[7] Buragga, Kh. A.M., \& Khan, M. A., "Successful ABET Accreditation at King Faisal University - Rubric based Assessment Plan for Continuous Improvement", WORLDCOMP'12 - The 2012 World Congress in Computer Science, Computer Engineering, and Applied Computing.

[8] Abet.org, "ABET - Accreditation: Step-by-Step", 2014 [online] Available at: http://www.abet.org/accreditationstep-by-step/

[9] Petrova, R., Tibrewal, A., \& Sobh, T. M., "An Electronic Web-based Assessment System", Journal of STEM Education, Vol. 7, Issue 3 \& 4, pp 44-57, 2006.

[10] South Africa., Pavaday, D., \& European Union. (2001). Building an ABET system: The first five years 1995-2000. Pretoria: Dept. of Education.

[11] Abet.org, (2014). ABET - Why Accreditation Matters. [online] Available at: http://www.abet.org/whyaccreditation-matters/

[12] Accreditation Policy and Procedure Manual. "Effect for Evaluations During 2011-2012 Accreditation Cycle", 2012.

[13] Felder, R. M. \& Brent, R., "Designing and Teaching Courses to Satisfy the ABET Engineering Criteria", Journal of Engineering Education, Vol. 92, No. 1, pp. 7$25,2003$.

[14] Spurlin, J. E., Rajala, S. A., \& Lavelle, J. P., "Designing better engineering education through assessment: A practical resource for faculty and department chairs on using assessment and ABET criteria to improve student learning”, 2008, Sterling, Va.: Stylus Pub..

[15] Buzzetto-More, N., \& Alade, A., "Best practices in eassessment", Journal of Information Technolog Education, Vol. 5, pp. 251-269, 2006.

[16] Kellough, R. D., \& Kellough, N. G.,"Secondary school teaching: A guide to methods and resources: Planning for competence", 1999, Upper Saddle River, New Jersey: 
Prentice Hall.

[17] McNeill, B. \& Bellamy, L., "The Articulation Matrix: A Tool for Defining and Assessing a Course", Chemical Engineering Education (CEE), Vol. 33, No. 2, pp.122-27, 1999.

[18] Bloom, B., "Taxonomy of Educational Objectives, Handbook I: Cognitive Domain", Longmans, Green and Co., 1956.

[19] Froyd, J. E., "Competency Matrix Assessment for FirstYear Curricula in Science, Engineering, and Mathematics and ABET Criteria 2000", ASEE/IEEE Frontiers in Education Conference, Pittsburgh, Pennsylvania, pp. 1190- 1195, 1997.

[20] Olds, B. M. \& Miller, R. L., “An Assessment Matrix for Evaluating Engineering Programs", Journal of Engineering Education, Vol. 87, No. 2, pp. 173-178, 1998

[21] Felder, R.M. \& Brent, R.,"Objectively speaking", Chemical Engineering Education. Vol. 31, No. 3, pp. 178-179, 1997.

\section{Authors' Profiles}

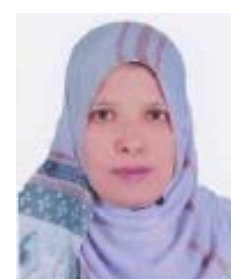

Sahar Abd El_Rahman was born in Cairo, Egypt, B.Sc. Electronics, Computer Systems \& communication, Electrical Engineering Department. Benha University, Shoubra Faculty of Engineering, CairoEgypt. M.Sc. in an AI Technique Applied to Machine Aided Translation, Electronic Engineering, Electrical Engineering Department, Benha University, Shoubra Faculty of Engineering, Cairo-Egypt, May2003. PHD. in Reconstruction of HighResolution Image from a Set of Low-Resolution Images, Electronic Engineering, Electrical Engineering Department,
Benha University, Shoubra Faculty of Engineering, Cairo-Egypt in Jan2008.

She is ASSISTANT PROFESSOR from 2011 till now at Princess Nourah Bint Abdulrahman University/Department of Computer Science, College of Computer and Information System. Also, She is ASSISTANT PROFESSOR from 2008 till now at Electronics \& communication, and Computer Systems, Electrical Engineering Department, Faculty of Engineering, Shoubra,, Benha University, Cairo, Egypt. She was a LECTURE in the same location from 2003 and INSTRUCTOR in the same location in 1998. Her research interests include computer vision, digital image processing, Signal processing, information security and cloud computing.

Sahar S. Shabanah was born in Saudi Arabia, B.Sc. from Computer Science Department, Faculty of Science, King Abdulaziz University, Saudi Arabia. M.Sc. Master degree from Computer Science Department, School of Engineering and Applied Science, George Washington University, USA, 2001. PHD. Computer Science Department, The Volgenau School of Information Technology and Engineering, George Mason University, USA, 2010.

She is ASSISTANT PROFESSOR from 2012 till now at Princess Nourah Bint Abdulrahman University/Department of Computer Science, College of Computer and Information System. Also, She is ASSISTANT PROFESSOR from 2010 till now at Department of Computer Sciences, Faculty of Computing and Information Technology, King Abdulaziz University. Her research interests include Computer Graphics, Animation, Computer Visualization, Computer Games Design and Development, Computer Science Education, Algorithms and Data Structures Visualization.

How to cite this paper: Sahar A. El_Rahman, Sahar S. Shabanah,"Course and Student Management System Based on ABET Computing Criteria", International Journal of Information Engineering and Electronic Business(IJIEEB), Vol.8, No.3, pp.1-10, 2016. DOI: 10.5815/ijieeb.2016.03.01 